\title{
EDUCATIONAL PROJECTS - SUPPORT FOR DEVELOPMENT OF TOURISM AND RURAL AREAS IN SERBIA
}

\author{
Jonel Subic $^{1}$, Zorica Vasiljevic ${ }^{2} \&$ Sanjin Ivanovic $^{3}$
}

\begin{abstract}
The paper presents three mini-projects that have been implemented by The Institute of Agricultural Economics - Belgrade in the 2006-2008 period. Those were special educational projects in agriculture and rural development, whereas extension activities were concentrated onto three topics: farm management, support of rural development and improvement of small farms. Implementation of projects took place on the territory of the South Banat County and some Belgrade city communes.

The projects intended to solve current problems of sustainable agriculture and rural development. Within the projects there were identified priorities related to investments, strategic planning and tourism. Educational activities were aimed at a number of holders or members of their registered farms. Dynamics of the projects' implementation included introduction and discussion with a number of farmers, formation of small groups, preparation and making of materials, a series of theoretical lectures and determination of the joint work results.

Education programs are aiming at improvement of the farm holders' knowledge in the field of business and management. Specific objectives of training are to increase sales of goods and services at domestic and foreign market, to increase competitiveness in a particular market, to achieve higher profits, to create new jobs and improve living conditions in rural areas. Evaluation of projects was related to determination of level, to which there were achieved set objectives, then to define implementation of projects in accordance with the plan, as well as to determine an impact of educational activities to promotion of knowledge concerning business and management.
\end{abstract}

Key words: education, rural areas, tourism, investments

\section{Introduction}

Adequate volume and structure of investments is necessary to provide useful increment of fixed and working assets, growth of employment, increase of labor and machinery productivity, production diversification etc. It is precondition for technical and technological modernization of agriculture and preconditions for stability of entire national economy.

In circumstances where agricultural activity is based on private owner structure, as well as opened and competitive market, investments should be realized in form which ensures maximal effectiveness of exploitation (as higher as possible achieved level of effects per unit of invested financial resources). Financial decisions making in agricultural practice (in all economic circumstances) should be based on strict quantitative and qualitative clauses. They will provide precise orientation of expenditures, i.e. investing in the most effective projects' variant. No matter who is an investor, he has to use adequate methods, techniques and models to evaluate economic effectiveness of investments in agriculture. In such a way the investor ensures that his financial resources are invested in appropriated way, and that they provide the best results not only for him but also for entire society (Cicea et al., 2008).
Rural areas in Serbia are involved in transitional process that has been under way for several years. Changes in domestic agrarian policy in sense of orientation towards rural development and multifunctional agriculture resulted in involvement of state institutions, local authorities and inhabitants of rural areas in development process. Such approach to rural development is the best way to facilitate integration in international institutions, European Union, and to strengthen over - border cooperation in this field, as well (Vasiljevic et al., 2008).

Rural development, as a rule, does not have concrete bearer (for example an enterprise). Complexity of rural development is connected to interests of many enterprises and other subjects; to interests of local population and other inhabitants. Keeping that fact in mind, state should incentive and support rural development. State is the only one that could use its territorial agencies and departments to start, realize and manage development of concrete territories.

To begin realization of rural development in certain territory it is necessary to finish a lot of work in preliminary stage. Such work includes professional and experts' engagement which is needed to establish development strategy. The strategy would represent foundation for undertaking of complex development activities.

\footnotetext{
1 Jonel Subic, Ph.D., Research Associate, Institute of Agricultural Economics, 15 Volgina Street, 11060 Belgrade, Serbia, e-mail: jonel_s@mail.iep.gb.ac.rs

2 Zorica Vasiljevic, Ph.D., Full Professor, Faculty of Agriculture, 6 Nemanjina Street, 11080 Zemun-Belgrade, Serbia, e-mail: vazor@agrif.bg.ac.rs

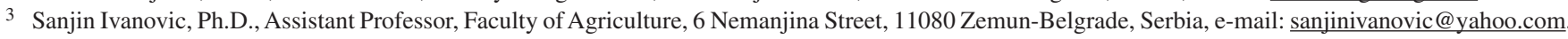


The most important element that is necessary to create development strategy is participation of all local community representatives in identification of existing possibilities and priorities which are important for local community.

Having in mind tendencies on tourist market (abandonment of mass tourism concept) recently is noticed increase of interest in so called "tourism of special needs". This is in accordance with fact that (on the end of last decade, as an act of political will) was promoted model of rural development (CAP). The model presents multifunctional nature of European agriculture and its development role in economy and entire society. Agriculture, as primary economy branch, has long term consequences for complementary cooperation with all economy sectors, so does with tourism (Vukovic et al., 2007).

Various tourist modes (such as rural tourism, hunting tourism, fishing tourism, sightseeing tourism, manifestation tourism) are some of activities which are accessible to rural areas inhabitants. However, tourism development does not have to be accidental or result of local inhabitants' gumption. It has to be subject of serious analysis and planning on all levels (local level, municipality level), in tourist organizations as well as in various enterprises which may have economic interest in tourism development. This is why it is necessary to use systemic approach in such activities. Education is a start point which is necessary and needed to build future development.

\section{Materials and methods}

There are two important objectives of education programs - the first (primary) goal of the programs is to raise the competitiveness of farms. Intention of the first objective is to improve their business and market efficiency, as well as to promote the provision of business services. The secondary goal is to develop tourism in Serbian rural areas as well as to involve more farmers in tourism activities. Achievement of above mentioned goals should improve farmers' business skills.

Bearing in mind complexity and requirements connected to implementation of accepted program, within mini-projects that have been implemented by The Institute of Agricultural Economics-Belgrade in the 2006-2008 periods, educational activity was directed only towards certain number of competent bearers (or family members of their registered farms). Hence, depending on size of settlement, educational program included no more than 20 attendants. Therefore, dynamics of project realization occurred in following way:

- First of all had been performed introduction and conversation with number of agricultural producers, and after that were formed small groups made up of chosen members;

- Followed preparation and making of working material in printed and electronic form;

- After that were performed series of theoretic lectures, as well as unavoidable workshops;
- During lectures was applied certain way of testing, in order to strengthen attendants' knowledge;

- On the end were summarized results of joint work, clarified all obscurities and participants agreed on future cooperation in project realization.

Activities concerning project named "Planning and appraisal of economic efficiency of investments on family farms ", had following dynamics of realization:

- Preparing activities (detour of the area; conversation to agricultural producers; choosing and forming of working groups; production, printing and multiplication of brochures as well as materials in electronic form);

- Educational activities of theoretical character (with topics: idea of investments; structure and classification of investments; characteristic of investments in agriculture);

- Educational activities of theoretical and practical character (with topics: planning of investments; basics of investment calculation; sources for financing of investments; idea of capital costs);

- Educational activities of theoretical and practical character (with topics: concept of economical efficiency; criteria for evaluation and analysis of economic efficiency of investments on micro economic level; time value of money and its importance for determination of economic efficiency of investments in agriculture etc.).

Activities regarding project named "Participation work on identification of possibilities and priorities in rural development of local community" had following dynamics of realization:

- Preparing activities (detour of the area; conversation to agricultural producers; choosing and forming of working groups; production, printing and multiplication of brochures as well as materials in electronic form);

- Educational activities of theoretical character (with topics: idea of rural development; idea of strategic planning; description of importance of strategic planning - theories and concepts; important factors/participants in rural development; usage of appropriate tools to define and analyze existing situation; SWOT analysis; methods for determination of priorities);

- Educational activities of theoretical and practical character (with topics: formation of data base, formation of development strategy; methods for preparations of strategic plans; implementation, supervision and promotion of strategic plans in rural development).

Activities related to project named "Tourism as a chance for development of rural areas" had following dynamics of realization: 
- Preparing activities (detour of the area; conversation to agricultural producers; choosing and forming of working groups; production, printing and multiplication of brochures as well as materials in electronic form);

- Educational activities of theoretical character (with topics: idea of tourism; characteristic of tourism as economical activity; complementarities of tourism and agriculture);

- Educational activities of theoretical and practical character (with topics: social and economical importance of tourism; organization of tourism in rural areas; marketing concept and its application in tourism; conditions and possibilities for development of tourism in rural areas; sustainable tourism development of rural areas; types of tourism; tourism of specific interests - chance for rural areas economic development).

Realization of the first project have taken place on the territory of Province of Vojvodina, in South Banat County (on the area of four agricultural municipalities: Pančevo, Kovačica, Opovo and Alibunar), realization of the second project have taken place on the territory of Central Serbia, in municipalities of the city of Belgrade (on the area of six agricultural municipalities: Palilula, Zemun, Surčin, Grocka, Obrenovac and Čukarica), while realization of the third project have taken place on the territory of Province of Vojvodina, in South Banat County (on the area of three agricultural municipalities: Pančevo, Kovačica and Alibunar).

Two-phase procedure was used to evaluate the project, where the first was done evaluation of individual project activities (preparatory and educational), and then was determined collective grade of the project (from 1 to 5). Accordingly, there were established following criteria: level of achievement of set objectives, level of project implementation in accordance with the plan and level of advancement of knowledge in the field of business and management.

\section{Results and discussion}

Within the project, participants had an opportunity to improve their theoretical knowledge and to perform adequate practical work. They developed necessary skills needed for planning and economic evaluation of investments at family farms, such as the following:

- to understand influence of usage of certain investment evaluation techniques and methods to investment decisions;

- to evaluate effectiveness of investment which is planed;

- to carry out cash flow analysis and to analyze investment projects' financing conditions;
- to avoid consequences of inefficient investing;

- to minimize risk that is associated with realization of business idea etc.

On the other hand, it is indicated an importance of economic efficiency of investments in agriculture. It is also determined necessity of education of agricultural producers (primarily bearers of developmentally orientated farms). They have to think out, prepare and realize business idea, which means to carry out planned investment activity that will enable their economic growth, financial stability and social safety.

Education within the first educational project was carried out in following intervals ${ }^{4}$ :

- from May, $15^{\text {th }} 2006$ to June, $15^{\text {th }} 2006$;

- from June, $20^{\text {th }} 2006$ to July, $20^{\text {th }} 2006$;

- from August, $14^{\text {th }} 2006$ to September, $14^{\text {th }} 2006$;

- from October, $23^{\text {rd }} 2006$ to November, $23^{\text {rd }} 2006$.

In all cases there were engaged three lecturers, regardless character of educational activity (theoretical or practical).

Based on the established evaluation criteria, following evaluation of project activities has been carried out: preparatory activities (grade 5), educational activities with theoretical character (grade 5), and educational activities with theoretical and practical character (grade 5). In this context, collective grade of the project has been determined (5).

On the basis of earned theoretical foundation and practical work in overwhelming of certain analytical knowledge which is necessary for planning and evaluation of undertaken actions for development of concrete rural area, representatives of local authorities have acquired following possibilities:

- to see how application of some methods influence decision making;

- to use certain models for priority determination;

- to take part in determination of development plans for their region;

- to monitor future development and improvement of development processes in appropriate way etc.

Besides, there was indicated importance that has local community representatives in identification of possibilities and priorities which are of the greatest importance for establishment of adequate data base. Data base which is formed in such a way should be used as basic for establishment of adequate strategy of concrete region development. Such regional strategy should be in accordance with national development strategy as much as possible. Cooperation between local community (on one side) and scientific and research institutions (on the other side) in recognition of crucial indicators of regional development is of great importance.

Education within the second educational project was carried out in following periods:

\footnotetext{
4 Time intervals were determined depending on engagement of project participants in everyday work on their farms (i.e. depending on intensity of works in agriculture).
} 
- from October, $1^{\text {st }} 2007$ to October, $31^{\text {st }} 2007$;

- from November, $1^{\text {st }} 2007$ to April, $30^{\text {th }} 2008$;

- from August, $1^{\text {st }} 2008$ to September, 30 2008.

There were always engaged three lecturers, no matter of character of educational activity (theoretical or practical work).

Based on established evaluation criteria, evaluation of conducted project activities was the following: preparatory activities (grade 5), educational activities with theoretical character (grade 4), and educational activities with theoretical and practical character (grade 4). Accordingly, collective grade of the project has been determined (4).

On the basis of theoretical lectures and practical work (regarding knowledge on tourism) agricultural producers which participated in education project have got basic knowledge needed for planning, organization, coordination and leading of all activities on the level of households and villages, as well as mini tourist agencies. In accordance with above mentioned, appear following possibilities:

- to grasp influence of tourism and its implementation to social and economic development of rural areas;

- to evaluate effectiveness and efficiency of tourism in realization of established goals and various interests;

- to grasp chances for development of own local community on the basis of available resources;

- to avoid consequences of omission of natural and social development potentials;

- to decrease risk of income realization etc.

Additionally, there was indicated importance of tourism for development of local communities and need for agricultural producers' education (primarily education of developmentally oriented farm bearers) regarding rural tourism activities. In rural areas tourism might present additional source of income for agricultural producers. Afterwards, in following development phases, for some households (which have mixed income sources) tourism could become bearer of development. There are expectations that tourism will enable economic growth, financial and social safety.

Education within the third educational project was carried out in following intervals:

- from October, $1^{\text {st }}$ to October, $31^{\text {st }} 2007$;

- from November, $1^{\text {st }} 2007$ to May, $1^{\text {st }} 2008$;

- from August, $1^{\text {st }} 2008$ to September, 30 2008.

Every time there were engaged four lecturers, and their engagement did not depend on type of educational activity (theoretical or practical character of work).

Project activities were evaluated on the basis of established evaluation criteria, in following way: preparatory activities (grade 5), educational activities with theoretical character (grade 4), and educational activities with theoretical and practical character (grade 4). In this context, collective grade of the project has been determined (4).

On the basis of above mentioned facts it is possible to conclude that the "Program of direct education of agricultural producers and bearers of rural development" started from basic assumptions and goals of strategic planning process. The program is founded on detail comprehension of local resources (material and non material) as well as local needs and potentials. There were deliberated basic theoretical elements, and complexity of economic, social, ecological and institutional components. This is start point for evaluation of existing social capital, promotion of desirable and elimination (or reduction) of undesirable processes and tendencies. The goal is to establish partnership between local participants. They have to determine, coordinate, optimize and carry out activities which provide long term increase of total life quality on local level.

Key elements that are necessary to create appropriate development strategy are participation of chosen local community representatives in identification of existing development possibilities, and determination of priorities which are important for local community.

Direct educational program enables local community representatives to qualify, and to improve their life quality in rural areas. Rural development of certain region significantly stimulates rural development in other regions (i.e. initiates rural development on national level) as well as in entire society. Implementation of special educational program in agriculture has following basic reasons:

- creation of vision concerning future goals of entire society;

- creation of overall picture regarding future changes in economy, environment and people;

- assurance of benefits for all society members;

- selection and consensus on basic common goals;

- involvement of number of local citizens and organizations in process of development planning and implementation;

- determination of resources which are needed for realization of changes;

- provision of support from state, private sector and non profit partners.

Territory, as a system, is under permanent evolution. The evolution is caused by endogen factors, development process, changeable and hardly predicted environmental factors. Thus, it is necessary to predict certain intervention during future socio - economic development of local rural communities. These interventions should be done to reroute programs, projects and other activities which are predicted in plans. Education of agricultural producers and bearers of rural development in order to enable them to identify development possibilities and priorities on local level is continual process.

Comparative analysis of evaluation of project activities, as well as the projects themselves as a whole, leads to the final conclusion that the education program on investments, entitled "'Planning and appraisal of economic efficiency of investments on family farms" has the most successful realization, and thus the highest collective grade (5). 


\section{Acknowledgements}

Paper work is a part of the project research 149007 of the Ministry of Science of Republic of Serbia „Multifunctional agriculture and rural development in function of accession of Republic of Serbia in European Union“.

\section{References}

Abay, A., Assefa, A. (2004): The role of education on the adoption of chemical fertilizer under different socioeconomic environments in Ethiopia. Agricultural Economics. Volume 30, Issue 3, p.p. 215-228.

Andrić, J., Vasiljević, Z., Sredojević, J., Z. (2005): Investicije osnove planiranja i analize, Univerzitet u Beogradu, Poljoprivredni fakultet, Beograd - Zemun.

Bogdanov, N. (2007): Mala ruralna domaceinstva u Srbiji i ruralna nepoljoprivredna ekonomija, Ministarstvo poljoprivrede, šumarstva i vodoprivrede Republike Srbije i UNDP, Beograd.

Cicea, C., Subic, J., Cvijanovic, D. (2008): Beyond Agriculture and Rural Development: Investments, Efficiency, Econometrics. Institute of Agricultural Economics, Belgrade.

Đurić, I., Subić, J., Onć-Jovanović, E., Kačarević, A. (2008): Participativni rad na identifikaciji moguanosti $i$ prioriteta $u$ ruralnom razvoju lokalne zajednice (Poseban projekat edukacije u poljoprivredi - Program direktne edukacije poljoprivrednih proizvoðača i nosilaca ruralnog razvoja - Podrška razvoju sela). Ministarstvo poljoprivrede, šumarstva i vodoprivrede Republike Srbije, Beograd.

Ellerbrock, M., Norton, Marjorie. (2000): Epistemological Foundations of Teaching and Learning through the Land-Grant System. Agricultural Economics. Volume 22, Issue 1, p.p. 218-227.

Hall, Parker, R. (2004): Perceptions of agricultural producers as participants of domestic farm policy programs: implications for education. Doctoral dissertation, Texas A\&M University.

Ivanovic, S., Subic, J., Sredojevic, Z. (2007): Financing of family farms in Serbia and its influence on business results. This book is the result of the conference "Values and Challenges in designing the European rural structures - research network experience" organized by IAE under CEXX Programme "Promovarea convergenpei regionale - modernizarea potenpialului științific În domeniul dezvoltării rurale" and in cooperation with ERDN (European Rural Development Network). Rural areas and development - vol. 5; p.p. 171-180.

Juvancic, L., Erjavec, E. (2005): Intertemporal analysis of employment decisions on agricultural holdings in Slovenia. Agricultural Economics. Volume 33, Issue 2, p.p. 153-161.

Ondersteijn, C. J. M., Giesen, G. W. J., Huirne, R. B. M. (2003): Identification of farmer characteristics and farm strategies explaining changes in environmental management and environmental and economic performance of dairy farms. Agricultural Systems. Volume 78, Issue 1, p.p. 31-55.

Subić, J., Jovanović, B., Stojsavljević, N. (2006): Planiranje $i$ procena opravdanosti investicije na poljoprivrednom gazdinstvu (Poseban projekat edukacije u poljoprivredi - Program direktne edukacije poljoprivrednih proizvoðača i nosilaca ruralnog razvoja na lokalu - Upravljanje farmom). Ministarstvo poljoprivrede, šumarstva i vodoprivrede Republike Srbije, Beograd.

Vasiljević, Z., Subić, J. (2008): Značaj bottom-up pristupa u planiranju $i$ realizaciji lokalnih $i$ regionalnih programa ruralnog $i$ poljoprivrednog razvoja u Srbiji. Predavanje po pozivu. Tematski zbornik Savetovanja Agrarna i ruralna politika Srbije 2, Početna iskustva pridruživanja EU i predlog mera za 2009. godinu (Agricultural and Rural Policy of Serbia 2, Initial Experiences of EU Accession and Proposal of Measures for 2009), Iriški venac, 9. oktobar 2008. DAES - Društvo agrarnih ekonomista Srbije, Beograd; p.p. 57-66.

Vuković, P., Hamović, V., Krgović, S. (2008): Turizam šansa razvoja ruralnih sredina (Poseban projekat edukacije u poljoprivredi - Program direktne edukacije poljoprivrednih proizvoðača i nosilaca ruralnog razvoja na lokalu - Unapreðenje malih poljoprivrednih gazdinstava). Ministarstvo poljoprivrede, šumarstva i vodoprivrede Republike Srbije, Beograd.

Vukovic, P., Subic, J., Cicea, C. (2007): Marketing Performing a Function in Tourist Development of Novi Sad. Petroleum - Gas University of Ploiesti, BULLETIN, Economic Sciences Series, Vol. LIX, N . 1/2007, p.p. 1-6.

Walters, B. B., Cadelina, A., Cardano, A., Visitacion, E. (1999): Community history and rural development: why some farmers participate more readily than others. Agricultural Systems. Volume 59, Issue 2, pp 193-214.

www.3sympatico.ca/david.macleod/RGECDV.HTM 